Article

\title{
Impacts of Salinity on Saint-Augustin Lake, Canada: Remediation Measures at Watershed Scale
}

\author{
Gaëlle Guesdon *, Ana de Santiago-Martín, Sébastien Raymond, Hamdi Messaoud, \\ Arthur Michaux, Samuel Roy and Rosa Galvez \\ Department of Civil and Water Engineering, Laval University, Quebec City, QC G1V 0A6, Canada; \\ ana.de-santiago-martin.1@ulaval.ca (A.d.S.-M.); sebastien.raymond@gci.ulaval.ca (S.R.); \\ hamdi.messaoud@gmail.com (H.M.); arthur.michaux@gadz.org (A.M.); samuel.roy.2@ulaval.ca (S.R.); \\ rosa.galvez@gci.ulaval.ca (R.G.) \\ * Correspondence: gaelle.guesdon@gci.ulaval.ca; Tel.: +1-418-656-2131
}

Academic Editors: Joan M. Brehm and Brian W. Eisenhauer

Received: 3 May 2016; Accepted: 5 July 2016; Published: 11 July 2016

\begin{abstract}
Winter road network management is a source of anthropogenic salinity in the Saint-Augustin Lake watershed (Quebec City, QC, Canada). To prevent the potential impact caused by road runoff involving de-icing salts $(\mathrm{NaCl})$ and trace metals $(\mathrm{Cd}$ and $\mathrm{Pb})$ on the watershed, a full-scale treatment chain system (including a detention basin, a filtering bed, and a constructed wetland) was built. Average $\mathrm{Cl}$ and $\mathrm{Na}$ concentrations in groundwater were higher in wells affected by road network ( $125 \mathrm{mg} / \mathrm{L} \mathrm{Cl}$ and $64 \mathrm{mg} / \mathrm{L} \mathrm{Na})$ than in control wells $(13 \mathrm{mg} / \mathrm{L} \mathrm{Cl}$ and $33 \mathrm{mg} / \mathrm{L} \mathrm{Na})$ suggesting a contamination by de-icing salts. The monitoring of influent and effluent surface water in the treatment system has shown a seasonal dependence in $\mathrm{NaCl}$ concentrations and electrical conductivity values, being the highest in summer, linked with the lower precipitation and higher temperature. Concentration ranges were as follows: $114-846 \mathrm{mg} / \mathrm{L} \mathrm{Na}$ and $158-1757 \mathrm{mg} / \mathrm{L} \mathrm{Cl}$ (summer) > 61-559 mg/L Na and 63-799 mg/L Cl (spring and autumn). The treatment system removal efficiency was significant, however with seasonal variations: $16 \%-20 \% \mathrm{Cl}, 3 \%-25 \% \mathrm{Na}$, $7 \%-10 \% \mathrm{Cd}$ and $7 \%-36 \% \mathrm{~Pb}$. The treatment system has shown an interesting potential to mitigate the impact of anthropogenic salinity at watershed scale with higher expected performances in the subsequent years of operation.
\end{abstract}

Keywords: de-icing salt; trace metals; surface water; groundwater; watershed; remediation; ecoengineering

\section{Introduction}

Over the past decades, road networks have been globally extended to support urban expansion. As such, road runoff has become an important cause of urban water quality deterioration [1]. Particulate matters, nutrients, hydrocarbons, and trace metals are part of the pollutants found in road runoff [2]. Additionally, northern countries with cold climate need to use large amounts of de-icing salts during winter on the entire road network in order to ensure safe driving conditions. In Canada, four million tons of salts per year to de-ice roads are used [3]. The Ministry of Transport of Quebec (MTQ) uses approximately 1.5 million tons of de-icing salts each year [4]. De-icing salts are essentially composed of sodium chloride $(\mathrm{NaCl})$ but can also be a complex mixture of calcium $(\mathrm{Ca})$, magnesium $(\mathrm{Mg})$, and potassium (K) ferrocyanide. Abrasive materials, such as gravel, are also used during snowstorms or freezing-rain events.

Winter practices are directly implicated in the origin of the anthropogenic salinity in watershed water (surface and groundwater). About $50 \%$ of the salt applied to paved road surfaces is transported via surface runoff, with the remaining $50 \%$ entering the subsurface as aquifer recharge [5]. Salinity 
has a significant impact on water ecosystems, producing toxicity to benthic and other freshwater organisms and affecting invertebrate reproduction [6]. As reported by Novotny and Stefan [7], de-icing salts can modify lake stratification and indirectly aggravate lake eutrophication processes by extending anoxia conditions and allowing the release of phosphates from organic sediment. The increase of salt concentration in groundwater is a concern for drinking water [8]. A high proportion of salts can also be accumulated in roadside soils and vegetation [9], which can affect soil physicochemical properties, biogeochemical cycles, and soil ecology. In addition, road runoff includes toxic trace metals such as $\mathrm{Cd}$ and $\mathrm{Pb}$ [10]. Indeed de-icing salts have a strong ability to increase trace metal mobility [11]. In addition, long-term use of de-icing salts can induce problems associated with chloride-induced corrosion of automobiles and road infrastructure (highway components, steel reinforcement bars, and concrete) and accelerates pavement deterioration due to freezing and thawing cycles [12]. Despite de-icing salts negative impact on the environment in the short and long term [13,14], at present it is difficult to stop or reduce its use for safety reasons. Therefore, strategies are aimed at preventing the potential impact caused from road runoff by reducing pollutant concentration. Nowadays, there are various strategies including constructed wetlands, oil and grit separators, and storm-water ponds, which are normally part of a treatment chain system [15]. However, few of these systems target the removal of de-icing salts from road runoff.

The 1970s construction of a road section of the Felix-Leclerc Highway A40 near Quebec City (Canada) has greatly contributed to water quality degradation in the Saint-Augustin Lake watershed. Several studies show that Saint-Augustin Lake water quality is being compromised by the increased human settlements around the watershed [16-18]. The proximity of the Highway A40 to Saint-Augustin Lake has induced surface water, groundwater, and sediment pollution by road de-icing salts and trace metals. Indeed, different water and sediment quality changes in Saint-Augustin Lake were observed after the Highway A40 construction: (i) high electrical conductivity (0.7-1.3 dS/m) in surface water was recorded with a positive relation with $\mathrm{Na}$ and $\mathrm{Cl}$ ions [10]; (ii) saltwater algae species are now present in the lake [17]; and (iii) high trace metal concentrations were measured in sediments [19]. Moreover, after the construction of the Highway A40, high electrical conductivity values and $\mathrm{NaCl}$ concentrations in groundwater were reported [20]. In order to mitigate the impacts of de-icing salts on water quality in the Saint-Augustin Lake watershed, a full-scale chain system to treat road runoff from Highway A40 was constructed. The treatment chain system was built in 2011 and includes a detention basin, an active filtering bed and an adapted constructed wetland.

This work concerns a field research project that includes the design of the system, its construction and monitoring program to evaluate groundwater and surface water quality in the Saint-Augustin Lake watershed, as well as system performance in the first and second years of operation. Specific discussion is made on the temporal variation patterns of $\mathrm{NaCl}$ and trace metals $(\mathrm{Cd}$ and $\mathrm{Pb})$, and other water quality indicators (temperature, $\mathrm{pH}$, electrical conductivity, and suspended solids).

\section{Materials and Methods}

\subsection{Site Description}

The water quality monitoring was conducted from spring 2012 to autumn 2013 in Saint-Augustin Lake watershed (flood plain of St. Laurent River, Saint-Augustin-de-Desmaures, QC, Canada), located in the municipal limit of Saint-Augustin-de-Desmaures (40 m altitude). The Saint-Augustin Lake watershed is located about $15 \mathrm{~km}$ in the west of Quebec City (Canada) and has an area of $7.64 \mathrm{~km}^{2}$ (Figure 1). Saint-Augustin Lake has a maximum dimension of $2.1 \mathrm{~km}$ in length, $0.3 \mathrm{~km}$ in width [21] and a depth average of $3.5 \mathrm{~m}$ [19]. The water renewal rate is estimated at 6 months and it is mainly driven by groundwater inflow [10]. Average annual temperature is $5.1^{\circ} \mathrm{C}$ and total annual precipitation (rainfall + water equivalent of the total snow) is $1109 \mathrm{~mm} /$ year for the 1998-2012 period (Station Jean Lesage, Quebec City, QC, Canada) [22]. The Saint-Augustin Lake watershed is included in two geological formations of the Paleozoic. The north-northwest of the watershed, including the lake is in the St. 
Lawrence Platform formation, upper and middle Ordovician. This formation is characterized by a rock composed of Mudrock, slate, dolomite and sandstone. The south part of the watershed is in the Appalachians Province, Ordovician to lower Silurian characterized by a rock composed of shale.
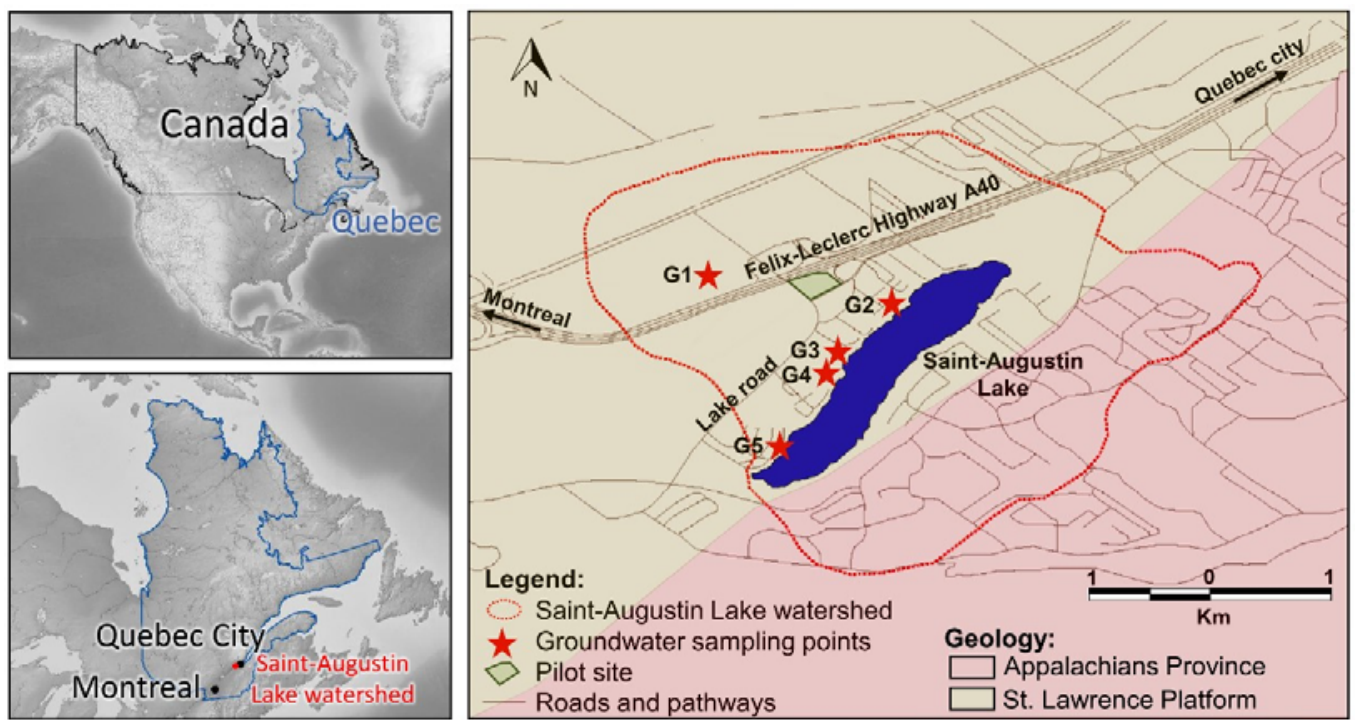

Figure 1. Groundwater sampling wells in Saint-Augustin Lake watershed (Quebec) and geological context. Red stars represent groundwater sampling wells: G1 (road control); G2 (residential control); and G3 to G5 (study wells affected by road and residential areas). Pilot site to runoff desalination is also indicated in the picture.

From 1960 onwards, population and land use have markedly changed. Conversion of forest to residential zones has become the dominant land use change. Currently, main land uses are agriculture, forestry, and residential, being $20 \%-25 \%, 20 \%$, and 30\% of the total area, respectively. In 1974, a section of Felix-Leclerc Highway A40 was constructed through part of the watershed (Figure 1) resulting in an increase in road traffic. Currently, the annual average daily traffic on this section is around 72,000 vehicles [23], which corresponds to a medium highway [2]. This construction was accompanied by increased population in the municipality [17]. In last decades, the electrical conductivity in water of Saint-Augustin Lake highly increased, coincident with the use of de-icing road salts on Highway A40 [10]. With the aim to deal with salt pollution in runoff water, in 2011 an environmental management solution (hereafter named pilot site) was constructed [24].

\subsection{Pilot Site Characteristic}

The pilot site is a treatment chain system composed of three units (Figure 2): (1) detention basin; (2) active filtering bed; and (3) free surface-flow adapted constructed wetland. The units were designed and constructed in 2011 in order to collect and treat approximately $25 \%$ of the Saint-Augustin Lake watershed's runoff water.

The pilot site was constructed within the limits of the Highway A40 ramp at the north of Saint-Augustin Lake. The site is compact and well integrated into the landscape with an area of $22,500 \mathrm{~m}^{2}$. Runoff is collected in a highway drainage ditch and accumulated in the detention basin before being redirected to the active filtering bed and/or the adapted constructed wetland (Figure 3).

The detention basin plays a role in the homogenization of the water collected from the highway ditch and in the regulation of flow water to the adapted constructed wetland and the active filtering bed. The detention basin accumulates road runoff and removes sediments and particles. The detention basin surface area is $340 \mathrm{~m}^{2}$ and the volume is $880 \mathrm{~m}^{3}$. 


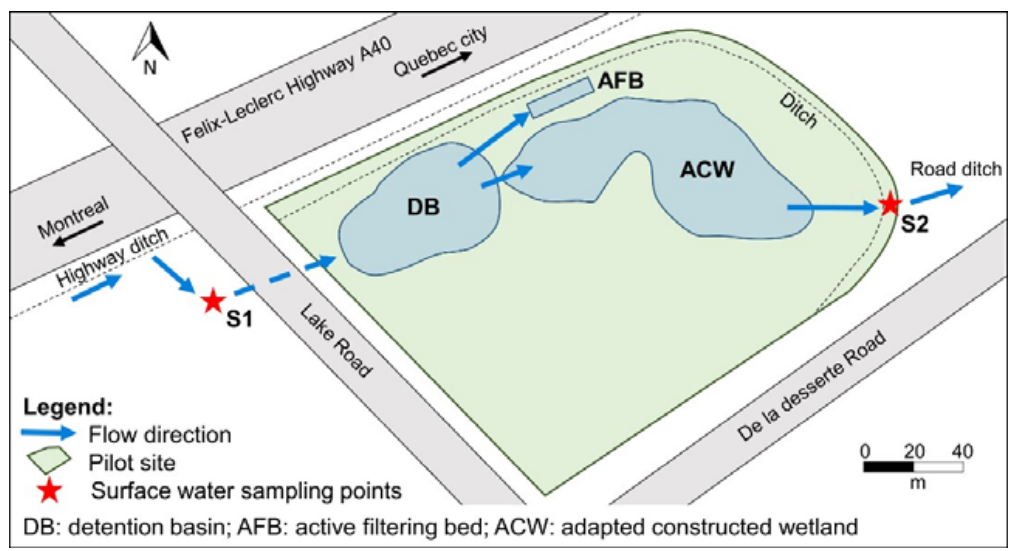

Figure 2. Surface water sampling points in the pilot site located in Saint-Augustin Lake watershed (Quebec). Red stars represent surface sampling points: S1 (influent water) and S2 (effluent water).

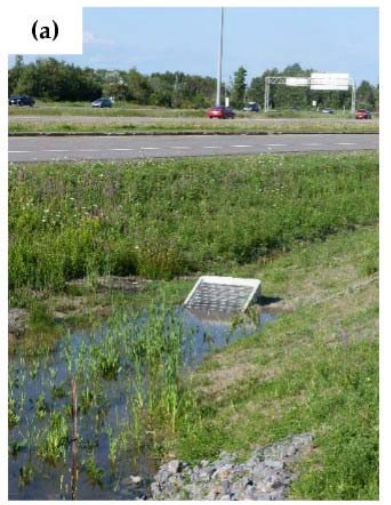

(b)
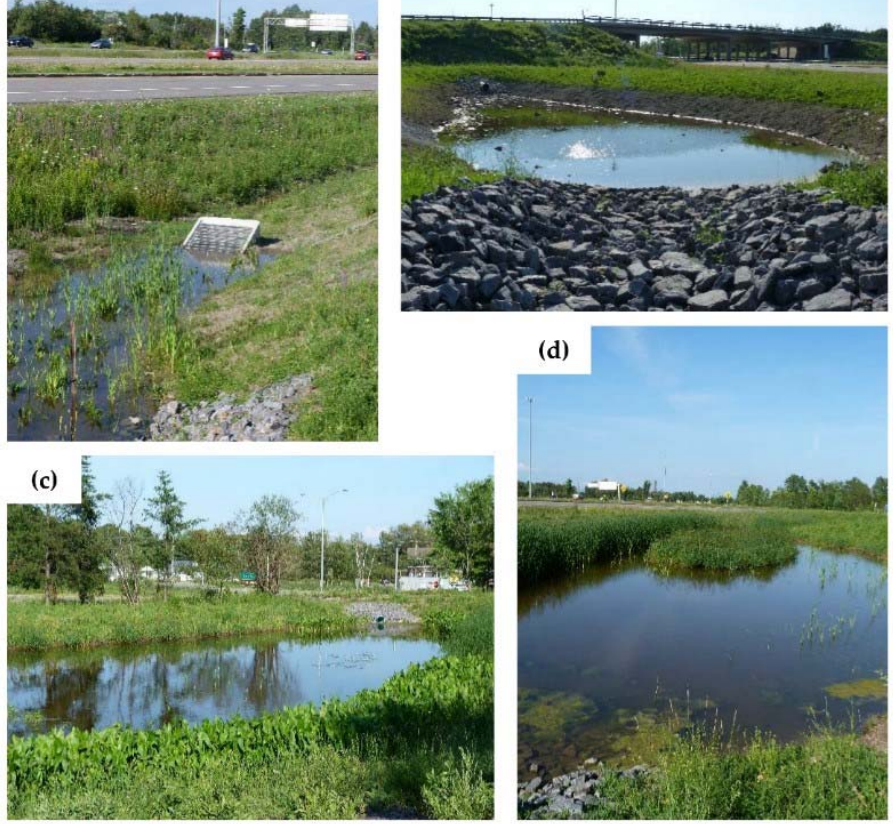

(d)

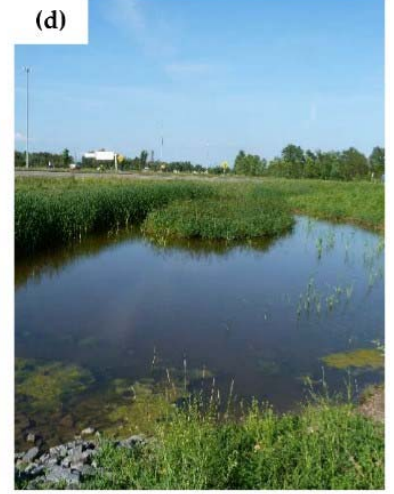

Figure 3. Pictures of the pilot site located in Saint-Augustin Lake watershed (Quebec): (a) active filtering bed entrance sump; (b) detention basin; (c) adapted constructed wetland-deep zone; and (d) adapted constructed wetland-shallow zone.

The active filtering bed uses an underground reactive media composed of a limestone $(80 \%)$ and dolomite $(20 \%)$ mixture. The functioning is based on the runoff circulating through a granular bed (the reactive media) whose chemical properties enhance contaminant retention. Clean stone from the reactive media has an average diameter between $5 \mathrm{~mm}$ and $10 \mathrm{~mm}$, which could ensure a permeability of $10 \mathrm{~cm} / \mathrm{s}$. The active filtering bed is $27 \mathrm{~m}$ long and $4.8 \mathrm{~m}$ wide (average width of the trapezoid), which gives a flow section of $2.88 \mathrm{~m}^{2}$. The active filtering bed is totally isolated from both soil and surface by an impermeable geotextile, and also from the base by the superposition of granular material and a geomembrane.

The adapted constructed wetland is a free surface-flow system where substrate, water and plants imitate the processes occurring in natural swamps. The adapted constructed wetland consists of a shallow pond divided into 3 plots of land where aquatic plants were cultivated. There is an inlet control equipped with a drainage pipe and a valve at the outlet that controls the water level as needed 
by the plants. The adapted constructed wetland dimensions are: $850 \mathrm{~m}^{3}$ volume and $5 / 1$ length/width. The bottom is impermeable, made from a bentonite geomembrane. Planted were typical wetland plants, such as Typha angustifolia and Eleocharis palustris. Moreover, halophyte plants were planted, such as Atriplex patula, Spergularia canadensis, and Salicornia europaea. Halophyte plants are an interesting alternative to plants traditionally used to treat the road effluents: (i) they are resistant to strong salinity; (ii) they can accumulate moderate to high quantities of salt in its biomass; and (iii) they can reduce the load of trace metals by bioaccumulation and biostabilisation $[9,24]$.

\subsection{Sampling Strategy}

\subsubsection{Groundwater}

A strategic sampling has been set up to characterize and monitor groundwater based on the location of the A40 highway, the rainwater drainage, and the piezometric and well network installed in the study area. Indeed, several sampling wells and piezometers are installed in the Saint-Augustin Lake watershed as part of previous research studies [20,25]. Based on these studies, several wells to collect groundwater samples were selected (Figure 1): piezometer G1 (road control); monitoring well G2 (residential control); and monitoring wells G3, G4, and G5 (study wells). Special attention was placed on the geological composition and land use of sites where selected wells are installed were as similar and comparable as possible. The piezometer G1 is located upstream of the Highway A40. In this area groundwater is not affected by runoff pollution from Highway A40. The G2 groundwater well is located in a residential area but away from the road area. In this area, groundwater is not affected by runoff pollution but by residences. Therefore, G1 and G2 are considered as reference monitoring points not affected by road de-icing salts due to its location. In contrast, the G3 to G5 groundwater wells are located upstream of Saint-Augustin Lake and placed in a North-West/South-East axis, being affected by both road and residential areas. Groundwater samples in duplicate were taken, with a single valve bailer, once a week from July to November 2013 (135 days) in order to monitor $\mathrm{Cl}$ and $\mathrm{Na}$ concentrations. Other major cations and anions $\left(\mathrm{K}^{+}, \mathrm{Ca}^{2+}, \mathrm{Mg}^{2+}, \mathrm{HCO}_{3}{ }^{-}, \mathrm{CO}_{3}{ }^{2-}, \mathrm{SO}_{4}{ }^{2-}\right.$, and $\left.\mathrm{PO}_{4}{ }^{3-}\right)$, as well as trace metals $(\mathrm{Cd}$ and $\mathrm{Pb})$, were also monitored in this period. Some water quality indicators (temperature, $\mathrm{pH}$, and electrical conductivity (EC)) were measured in situ using a multiprobe meter (Model YSI 6600 V2, YSI Inc., Yellow Springs, OH, USA). Water level was measured with an electrical probe called "Deep water level".

\subsubsection{Surface Water}

Surface water was sampled and monitored in all cases at two points at the pilot site (Figure 2). The first sampling point (S1) is located in a Highway A40 ditch at the entrance of the pilot site corresponding to influent water. The second sampling point (S2) is located at the exit of the pilot site corresponding to treated water or effluent water. Pilot site construction and plantation were finished during summer 2011. Between July and October 2011 some water quality indicators were measured in situ (temperature, $\mathrm{pH}$, and EC) or in the laboratory (total suspended solids (TSS)). Then, the system was allowed to stabilize until spring 2012 (snow-melting period), when the monitoring was conducted. Surface water samples were taken once a week from March to November 2012 (238 days) in order to monitor $\mathrm{Cl}$ and $\mathrm{Na}$ concentrations, water quality indicators (temperature, $\mathrm{pH}, \mathrm{EC}$, and TSS), as well as trace metal concentrations ( $\mathrm{Cd}$ and $\mathrm{Pb}$ ). Removal efficiency (\%) of $\mathrm{Na}, \mathrm{Cl}, \mathrm{Cd}$, and $\mathrm{Pb}$ was calculated in terms of concentration by the following Equation (1):

$$
\text { Removal efficiency }=\frac{C_{\text {in }}-C_{\text {out }}}{C_{\text {in }}} \times 100
$$

where $C_{\text {in }}$ and $C_{\text {out }}$ are the average influent and effluent concentrations, respectively, of $\mathrm{Na}, \mathrm{Cl}, \mathrm{Cd}$, or $\mathrm{Pb}(\mathrm{mg} / \mathrm{L})$. 


\subsection{Analytical Methods}

The collected ground and surface water samples were filtered under vacuum through a $0.45-\mu \mathrm{m}$-pore-size cellulose ester membrane filter (Advantec Inc., Montreal, QC, Canada). Then the filtrate was frozen (for major anion quantification) or acidified to $\mathrm{pH} 2$ by adding the necessary volume of concentrated $\mathrm{HNO}_{3}$ and kept at $4{ }^{\circ} \mathrm{C}$ until analysis (for major cation and trace metal quantification). Major anions $\left(\mathrm{Cl}^{-}, \mathrm{HCO}_{3}{ }^{-}, \mathrm{CO}_{3}{ }^{2-}, \mathrm{SO}_{4}{ }^{2-}\right.$, and $\left.\mathrm{PO}_{4}{ }^{3-}\right)$ were quantified by high performance liquid chromatography (1525 Binary HPLC Pump System, Waters Inc., Brossard, QC, Canada). Major cations were quantified by flame atomic emission $(\mathrm{Na})$ or absorption $(\mathrm{K}, \mathrm{Ca}, \mathrm{Mg})$ spectroscopy (AA240FS, Varian Inc., Mississauga, $\mathrm{ON}$, Canada). Trace metals $(\mathrm{Cd}, \mathrm{Pb})$ were quantified by graphite furnace atomic absorption spectroscopy with Zeeman background correction (AA240Z, Varian Inc.). Detection limits in $\mu \mathrm{g} / \mathrm{L}$ were: $\mathrm{Cd}=0.01, \mathrm{~Pb}=0.2, \mathrm{Na}=2, \mathrm{~K}=30, \mathrm{Ca}=10, \mathrm{Mg}=3$ (spectroscopy method), $\mathrm{Cl}^{-}=25, \mathrm{HCO}_{3}{ }^{-}=50, \mathrm{CO}_{3}{ }^{2-}=50, \mathrm{SO}_{4}{ }^{2-}=75, \mathrm{PO}_{4}{ }^{3-}=125$ (HPLC method). Total suspended solid quantification was conducted following standard analytic procedures [26]. All chemicals and reagents were analytic grade from Fisher Scientific Inc. (Ottawa, ON, Canada) and EMD Chemicals Inc. (Etobicoke, ON, Canada). All glassware used was rinsed with nanopure water (Ultrapure Water System, Barnstead Nanopure, Mississauga, ON, Canada).

\subsection{Statistical Analyses}

Significance of differences of $\mathrm{Cl}, \mathrm{Na}, \mathrm{Cd}, \mathrm{Pb}$, TSS concentrations and temperature, $\mathrm{pH}, \mathrm{EC}$ values between influent and effluent surface water (S1 and S2) were investigated by means of $t$-student test. Pearson correlation coefficients were calculated to relate water parameters to each other in order to support data interpretation. Analyses were conducted using Statistical Package for the Social Sciences v. 17 (SPSS Inc., Amonk, NY, USA) software. Graphics were created using GraphPad Prism v. 6.01 software (GraphPad Inc., La Jolla, CA, USA).

\section{Results and Discussion}

\subsection{Groundwater Quality}

\subsubsection{Hydrochemical Groundwater Characterization}

The Stiff diagram (Figure 4) represents the hydrochemical groundwater characterization in the wells G1 (road control well positioned upstream the Highway A40), G2 (residential control well), and G3, G4 and G5 (study wells), based on the monitoring conducted between July and November 2013.

Stiff diagram representation allows the mapping, for each well, of a polygon that assumes a geometry depending on the content of hydrochemical elements and gives an idea of the dominant species and its chemical relationship. The three axes of the diagram are, respectively, up to down: (1) $\mathrm{Na}^{+}-\mathrm{K}^{+}-\mathrm{Cl}^{-}$; (2) $\mathrm{Ca}^{2+}-\mathrm{HCO}_{3}{ }^{-}-\mathrm{CO}_{3}{ }^{2-}$; and (3) $\mathrm{Mg}^{2+}-\mathrm{SO}_{4}{ }^{2-}$. As shown in Figure 4, higher $\mathrm{HCO}_{3}{ }^{-}$ and $\mathrm{Ca}^{2+}$ contents were measured in groundwater from G1 and G5 wells. Stiff diagrams allow the chemical classification of the waters according to the anion and cation facies. In this regard, the water type that corresponds to the groundwater sampled in G1 and G5 wells was calcium-sodium bicarbonate-chloride sulphate. Interestingly, EC mean values in groundwater were higher in these wells ( 0.75 and $0.84 \mathrm{dS} / \mathrm{m}, \mathrm{G} 1$ and G5, respectively) than in the others $(0.25-0.56 \mathrm{dS} / \mathrm{m})$. The other wells (G2, G3, and G4) presented a different hydrochemical water type based on their chemical composition. Indeed, groundwater samples collected in the G2 well were sodium-calcium bicarbonate-chloride sulphate type. In the study wells, the water-type profiles were calcium-sodium chloride-sulphate bicarbonate (the G3 well) and sodium-calcium chloride-sulphate bicarbonate (the G4 well). The relative heterogeneity of results corresponds to the alluvial nature of soils in the study area. The agricultural lands that are in proximity to the G1 well could be partially responsible of its high $\mathrm{HCO}_{3}{ }^{-}$ and $\mathrm{Ca}^{2+}$ contents, although this would not explain the data of G5. Indeed, results are consistent with the most common facies found in the territory of the Metropolitan Community of Quebec 
City $\left(\mathrm{Ca}^{2+}-\mathrm{HCO}_{3}{ }^{-}\right.$and $\mathrm{Na}^{+}-\mathrm{Cl}^{-}$, associated with recharge areas), and show the typical intrinsic heterogeneity in the spatial distribution of geological deposits of glaciofluvial origin [27]. These facies are found almost exclusively on the north shore of the St. Lawrence River, in the St. Lawrence Platform formation.

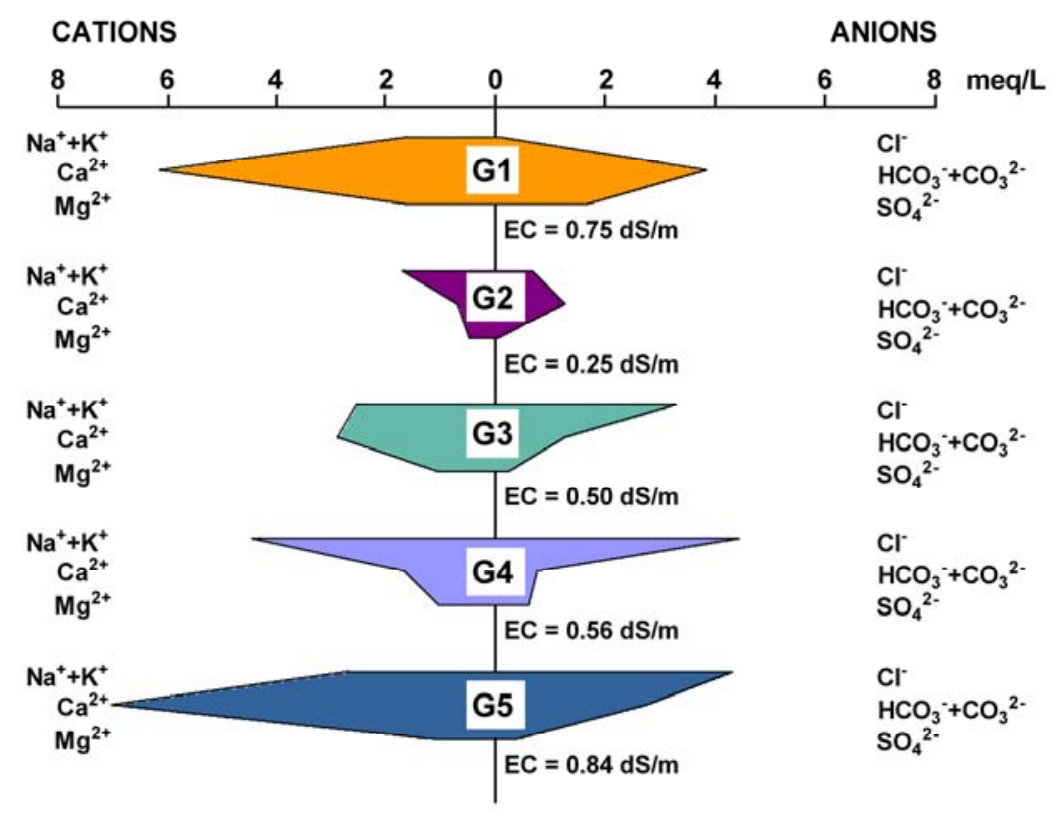

Figure 4. Stiff diagram of the groundwater of sampling wells (G1, road control; G2, residential control; and G3 to G5, study wells). For each ion, data are expressed as mean values (meq/L) of the monitoring performed from summer to autumn 2013. EC: electrical conductivity.

Overall, the groundwater sampled in the study wells (G3 to G5) is much more loaded in $\mathrm{Cl}$ than in G1 and G2 control wells: 54\% (G3), 67\% (G4), and 42\% (G5) of the sum of ions. As discussed below, results suggest that the road runoff loaded with $\mathrm{Cl}$ from de-icing salts leached into the soil and reached the groundwater downstream of the road network. In contrast, $\mathrm{Na}$ was not always the predominant cation in the study wells. This is probably because of $\mathrm{Na}$ ions are more easily retained in soils than $\mathrm{Cl}$ ions and, therefore, lower $\mathrm{Na}$ concentrations in groundwater are expected. If we consider the predominant ions: $\mathrm{HCO}_{3}{ }^{-}$was the predominant anion ( $>50 \%$ of the sum of anions) in groundwater in G1, G2, and G5 wells, and Cl in G3 and G4 wells. Considering the cations, Ca was predominant in G1, G3, and G5 wells, but Na in G2 and G4 wells.

Within the groundwater characterization, trace metal $(\mathrm{Cd}$ and $\mathrm{Pb})$ concentration was also monitored. However, $\mathrm{Cd}$ and $\mathrm{Pb}$ concentrations were in all cases below the detection limit.

\subsubsection{Water Quality Indicators}

Groundwater quality indicators (temperature, pH and EC) in G1, G2, G3, G4 and G5 wells were monitored during summer and autumn seasons and are presented in Figure 5.

The groundwater temperatures ranged from $10{ }^{\circ} \mathrm{C}$ to $13{ }^{\circ} \mathrm{C}$ (Figure 5a). An increase in groundwater temperature was observed during the summer period, with a decrease in autumn. The highest temperatures were measured in the G1 well, road control (during the summer period), and the smallest values in the G2 well, residential control. The temperatures in groundwater in the G3 to G5 wells were intermediaries.

Regarding $\mathrm{pH}$ (Figure 5b), no clear temporal variation pattern was observed. Values fluctuated from 5.6 to 8.3 in the G3 to G5 wells. In the case of control wells, the $\mathrm{pH}$ values in G1 were neutral (around 7) while $\mathrm{pHs}$ tended to basicity in the G2 with values $\geqslant 8$. The lowest $\mathrm{pH}$ values were measured in the G4 and G5 study wells. Relationships between the $\mathrm{pH}$ values and the other measured 
water parameters were not observed. Differences in the content and composition of some reactive fractions (carbonate, organic matter, etc.) of soils located in the area of the wells, mainly due to different lithology and land use, may account for the observed $\mathrm{pH}$ range.
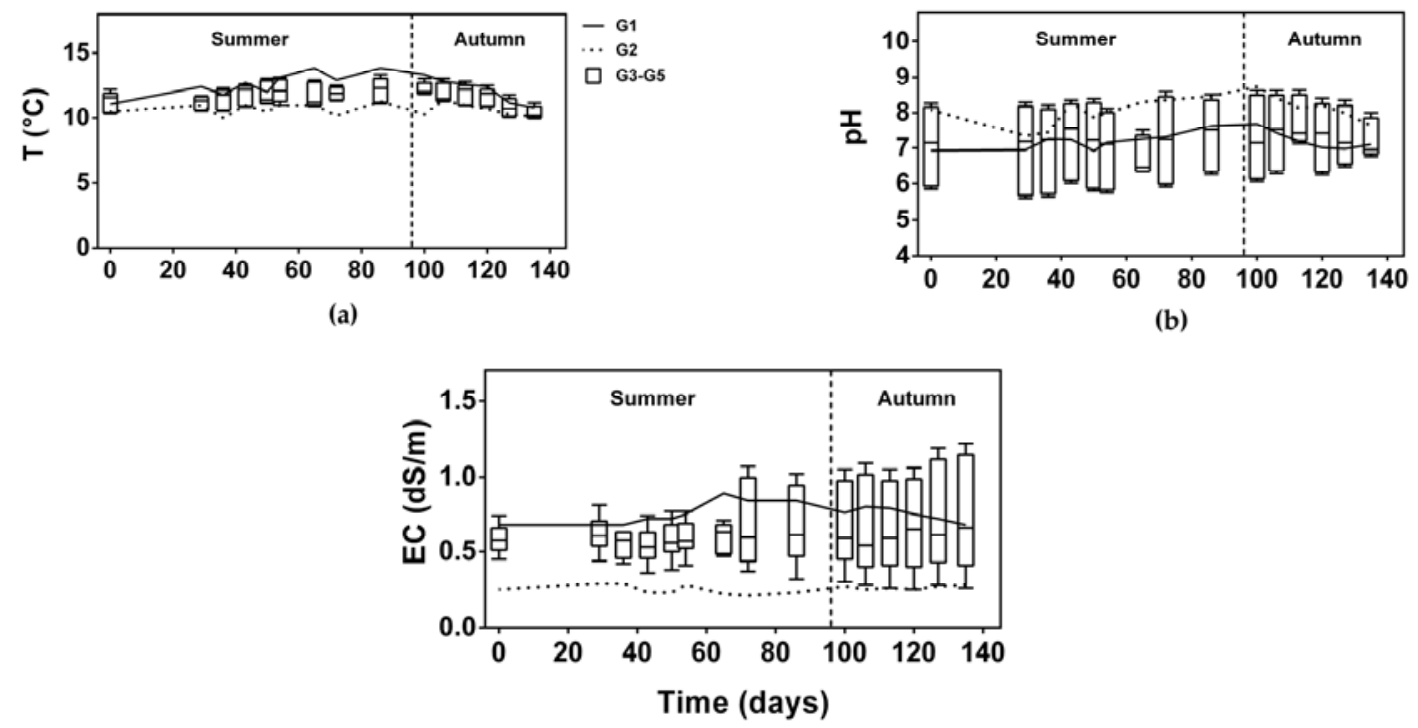

(c)

Figure 5. Water quality indicators in groundwater sampling wells (G1, road control; G2, residential control; and G3 to G5, study wells) for the monitoring performed from summer to autumn 2013: (a) temperature ( $\mathrm{T}) ;(\mathbf{b}) \mathrm{pH}$ and (c) electrical conductivity (EC). Solid and dotted lines represent mean values for G1 and G2, respectively. Boxplots show the lower, median, and upper quartiles for G3-G5, with whiskers extending to the most extreme data point.

Figure 5c shows the EC values in groundwater sampled in control and study wells over time. As explained above, significant differences among EC values in the road control well (G1) and the study wells (G3-G5) could not be established. In contrast, the G2 well showed the lowest EC values $(0.25 \mathrm{dS} / \mathrm{m})$. In order to support the discussion, Pearson's correlation analysis was performed (Table 1). Interestingly, EC was highly significant and positively correlated with $\mathrm{Cl}$ in the study wells $(p<0.001)$ but not in the control wells. This showed a differentiating pattern between control and study wells and suggested that the EC measured in the study wells (G3, G4 and G5) would be mostly due to the $\mathrm{NaCl}$ content, in contrast to control wells. Pearson's correlations were also calculated among EC values and the other major anions and cations. The EC values over time were significantly and positively correlated with: (i) $\mathrm{Ca}^{2+}$ in the G1, G3 and G5 wells ( $p<0.001$ ); (ii) $\mathrm{HCO}_{3}{ }^{-}$in the G1, G2, and G5 wells ( $p<0.001$ ); (iii) $\mathrm{Mg}^{2+}$ in the G3 and G5 wells $(p<0.001)$; and (iv) $\mathrm{SO}_{4}{ }^{2-}$ in the G1 $(p<0.01)$, G3 and G5 wells $(p<0.001)$. As stated above, groundwater in the G1, G3 and G5 wells belongs to the calcium-sodium facies, which is affecting its EC values. As described above, the intrinsic heterogeneity of the study area could be partially responsible of the EC spatial pattern. Results therefore suggest that the EC spatial pattern in the groundwater of the selected wells is determined by both anthropic (de-icing salts; G3, G4 and G5 wells) and natural influences (weathering of rocks and leaching of ions from soil; G1, G3 and G5 wells). 
Table 1. Pearson's correlation coefficients among groundwater parameters at each well.

\begin{tabular}{|c|c|c|c|c|c|c|c|c|c|c|c|c|}
\hline Well & Parameters & $\mathbf{T}$ & $\mathrm{pH}$ & EC & WL & $\mathrm{Cl}^{-}$ & $\mathrm{Na}^{+}$ & $\mathrm{Ca}^{2+}$ & $\mathrm{Mg}^{2+}$ & $\mathbf{K}^{+}$ & $\mathrm{HCO}_{3}{ }^{-}$ & $\mathrm{SO}_{4}{ }^{2-}$ \\
\hline \multirow{6}{*}{ G1 } & $\mathrm{T}$ & 1 & $0.674^{* *}$ & $0.788^{* * *}$ & 0.611 * & -0.458 & -0.252 & $0.696 * *$ & 0.506 & $0.588^{*}$ & $0.813 * * *$ & 0.472 \\
\hline & $\mathrm{pH}$ & & 1 & 0.549 * & 0.234 & -0.395 & -0.192 & $0.553 *$ & 0.458 & 0.251 & 0.368 & 0.416 \\
\hline & $\mathrm{EC}$ & & & 1 & 0.368 & $-0.514 *$ & -0.224 & $0.968^{* * *}$ & 0.366 & $0.708^{* *}$ & $0.879 * * *$ & $0.660 * *$ \\
\hline & WL & & & & 1 & 0.075 & 0.057 & 0.176 & $0.680 * *$ & $0.568 *$ & $0.535 *$ & 0.067 \\
\hline & $\mathrm{Cl}^{-}$ & & & & & 1 & 0.547 * & $-0.544^{*}$ & -0.398 & -0.252 & -0.437 & -0.438 \\
\hline & $\mathrm{Na}^{+}$ & & & & & & 1 & -0.321 & -0.344 & 0.056 & -0.336 & 0.092 \\
\hline \multirow{6}{*}{ G2 } & $\mathrm{T}$ & 1 & 0.309 & -0.220 & 0.167 & 0.021 & -0.367 & -0.105 & -0.247 & -0.260 & -0.122 & 0.330 \\
\hline & $\mathrm{pH}$ & & 1 & $-0.593 *$ & 0.474 & 0.413 & -0.146 & -0.503 & $-0.672 * *$ & -0.207 & $-0.593 *$ & -0.145 \\
\hline & $\mathrm{EC}$ & & & 1 & -0.109 & 0.232 & 0.335 & $0.532 *$ & $0.520 *$ & 0.356 & $0.930 * * *$ & -0.157 \\
\hline & WL & & & & 1 & 0.506 & -0.162 & -0.201 & -0.168 & 0.350 & -0.137 & -0.009 \\
\hline & $\mathrm{Cl}^{-}$ & & & & & 1 & 0.307 & -0.269 & -0.150 & 0.258 & 0.063 & -0.085 \\
\hline & $\mathrm{Na}^{+}$ & & & & & & 1 & -0.048 & 0.230 & 0.311 & 0.014 & 0.024 \\
\hline \multirow{6}{*}{ G3 } & $\mathrm{T}$ & 1 & -0.270 & 0.472 & $0.554 *$ & $0.563 *$ & 0.148 & 0.392 & 0.400 & -0.440 & -0.198 & 0.283 \\
\hline & $\mathrm{pH}$ & & 1 & $-0.876^{* * *}$ & $-0.727 * *$ & $-0.903 * * *$ & -0.442 & $-0.871^{* * *}$ & $-0.725^{* *}$ & 0.100 & 0.350 & $-0.905^{* * *}$ \\
\hline & $\mathrm{EC}$ & & & 1 & $0.808 * * *$ & $0.951 * * *$ & 0.405 & $0.968 * * *$ & $0.889 * * *$ & -0.201 & -0.076 & $0.916^{* * *}$ \\
\hline & WL & & & & 1 & $0.822 * * *$ & 0.337 & $0.769 * *$ & $0.668^{* *}$ & -0.087 & -0.226 & $0.778 * *$ \\
\hline & $\mathrm{Cl}^{-}$ & & & & & 1 & 0.508 & $0.889 * * *$ & $0.754 * *$ & -0.288 & -0.293 & $0.872 * * *$ \\
\hline & $\mathrm{Na}^{+}$ & & & & & & 1 & 0.304 & 0.143 & -0.089 & $-0.518 *$ & 0.466 \\
\hline \multirow{6}{*}{ G4 } & $\mathrm{T}$ & 1 & -0.259 & -0.349 & 0.334 & -0.323 & -0.133 & -0.499 & -0.185 & 0.378 & -0.328 & 0.412 \\
\hline & $\mathrm{pH}$ & & 1 & 0.615 * & 0.618 * & $0.605^{*}$ & $0.542 *$ & 0.399 & 0.283 & -0.238 & 0.258 & -0.446 \\
\hline & $\mathrm{EC}$ & & & 1 & 0.280 & $0.787 * * *$ & $0.881 * * *$ & 0.495 & 0.447 & -0.219 & 0.591 * & -0.510 \\
\hline & WL & & & & 1 & 0.251 & 0.387 & 0.035 & 0.366 & 0.046 & 0.035 & -0.438 \\
\hline & $\mathrm{Cl}^{-}$ & & & & & 1 & 0.551 * & 0.367 & 0.458 & -0.466 & 0.120 & -0.342 \\
\hline & $\mathrm{Na}^{+}$ & & & & & & 1 & 0.295 & $0.534 *$ & -0.109 & 0.469 & $-0.530 *$ \\
\hline \multirow{6}{*}{ G5 } & $\mathrm{T}$ & 1 & 0.059 & 0.287 & 0.454 & 0.287 & 0.156 & 0.302 & 0.255 & 0.138 & 0.233 & 0.238 \\
\hline & $\mathrm{pH}$ & & 1 & $-0.661^{* *}$ & $-0.600 *$ & $-0.694^{* *}$ & -0.510 & $-0.660 * *$ & $-0.681^{* *}$ & 0.059 & $-0.528 *$ & $-0.689 * *$ \\
\hline & $\mathrm{EC}$ & & & 1 & $0.946^{* * *}$ & $0.973 * * *$ & $0.818^{* * *}$ & $0.989 * * *$ & $0.950 * * *$ & 0.295 & $0.937^{* * *}$ & $0.978 * * *$ \\
\hline & WL & & & & 1 & $0.941^{* * *}$ & $0.704^{* *}$ & $0.930 * * *$ & $0.905^{* * *}$ & 0.145 & $0.897 * * *$ & $0.886^{* * *}$ \\
\hline & $\mathrm{Cl}^{-}$ & & & & & 1 & $0.751 * *$ & $0.944^{* * *}$ & $0.952 * * *$ & 0.276 & $0.888^{* * *}$ & $0.952 * * *$ \\
\hline & $\mathrm{Na}^{+}$ & & & & & & 1 & $0.788^{* * *}$ & $0.777^{* *}$ & 0.318 & $0.700 * *$ & $0.833^{* * *}$ \\
\hline
\end{tabular}

Notes: T: Temperature; EC: Electrical conductivity; WT: Water level. ${ }^{*} p<0.05 ;{ }^{* *} p<0.01 ;{ }^{* * *} p<0.001$, statistical significance at these probability levels $(n=15)$. 
Regarding the temporal pattern, although mean EC values in control wells remained almost constant throughout the study period $(0.68-0.89 \mathrm{dS} / \mathrm{m}$ in G1 and $0.21-0.29 \mathrm{dS} / \mathrm{m}$ in G2), a different pattern was observed in the study wells (G3, G4 and G5). Thus, the range of variation is much larger in autumn (linked with more precipitation) than in summer. When the EC values in groundwater are evaluated separately taking into account each of the study wells, it was observed that EC: decreases (from 0.64 to $0.36 \mathrm{dS} / \mathrm{m}$ in G3), is almost constant (from 0.53 to $0.63 \mathrm{dS} / \mathrm{m}$ in G4), or increases (from 0.58 to $1.17 \mathrm{dS} / \mathrm{m}$ in G5) over time. Results were compared to the water levels measured at each well over time (data not shown). Pearson correlation analysis showed significant and positive correlations between EC values and the water level in the G3 and G5 wells $(p<0.001)$ (Table 1). Results therefore showed that the higher the water level, the higher the EC in groundwater and that this pattern was not apparently seasonally dependent. Nonetheless, the longer residence time of groundwater than that of surface water could be offsetting the seasonal pattern. Higher infiltration of water charged in salts during the increase of water levels may account for the positive correlation obtained between the EC values and the water level, which deserves further studies.

\subsection{3. $\mathrm{NaCl}$ Concentration}

The concentration of $\mathrm{Cl}$ and $\mathrm{Na}$ in groundwater (G1 to G5 wells) has been monitored from summer to autumn 2013 (Figure 6).
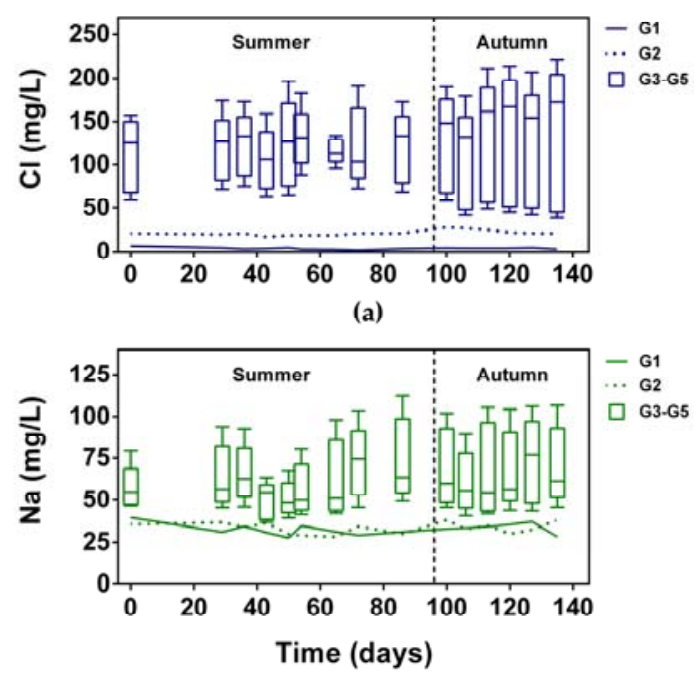

(b)

Figure 6. Concentration of $\mathrm{Cl}$ and $\mathrm{Na}$ in groundwater sampling wells (G1, road control; G2, residential control; and G3 to G5, study wells) for the monitoring performed from summer to autumn 2013: (a) Cl and (b) Na. Solid and dottedlines represent mean values for G1 and G2, respectively. Boxplots show the lower, median, and upper quartiles for G3-G5, with whiskers extending to the most extreme data point.

The $\mathrm{Cl}$ concentration in groundwater in the two control wells (4 and $22 \mathrm{mg} / \mathrm{L}$ in G1 and G2 respectively, $\sim 13 \mathrm{mg} / \mathrm{L}$ on average) was in all cases lower than that quantified in the study wells (from 39 to $222 \mathrm{~g} / \mathrm{L}, 125 \mathrm{mg} / \mathrm{L}$ on average, G3-G5). Interestingly, results showed that even though major ion concentrations (Figure 4) and EC values (Figure 5) are elevated in G1 well, Na and Cl concentrations are very low (Figure 6). The higher $\mathrm{Cl}$ concentrations obtained in $\mathrm{G} 2$ with respect to G1 can be explained by the residential character of the area. Indeed, septic tanks are possible sources of groundwater salinization [8]. The higher $\mathrm{Cl}$ concentration in groundwater in the study wells (G3 to G5) than in the control wells (G1 and G2) indicates that the road network and de-icing salts impact the groundwater chemical composition. This observation was also stated by Daley et al. [8], which reported that sewage and water softeners accounted for only $7 \%$ of the $\mathrm{Na}$ and $\mathrm{Cl}$ input to a single 
rural watershed in New Hampshire, whereas $\mathrm{NaCl}$ used for de-icing accounted for $91 \%$. Regarding $\mathrm{Na}$, the same pattern was observed as in the case of $\mathrm{Cl}$. Thus, Na concentration in groundwater in the two control wells (G1 and G2) showed the lowest values ( $33 \mathrm{mg} / \mathrm{L}$ on average). In the case of the study wells (64 mg/L Na on average, G3-G5), the maximum Na values even reached up to $112 \mathrm{mg} / \mathrm{L}$. This showed the importance of the Highway and road network on the contamination of groundwater. As it was observed for $\mathrm{EC}$, the range of variability in $\mathrm{Cl}$ concentration in the study wells was higher in autumn than in summer, attributed to the cooler temperatures and higher precipitation rates during autumn, which facilitates flushing of salts through groundwater. A relationship with the water level was also observed (Table 1). Thus, significant and positive correlations among the water level were obtained with $\mathrm{Cl}$ in the G3 and G5 wells $(p<0.001)$ and with Na in the G5 well $(p<0.01)$. As stated above, $\mathrm{EC}$ and $\mathrm{Cl}$ and $\mathrm{Na}$ ions were significantly positively correlated to each other in the study wells $(p<0.001)$ but not in the control wells. These results are in accordance with the study conducted by Galvez-Cloutier et al. [20] for the same lake and season.

Groundwater is an important source of drinking water. According to McConnell and Lewis [28], $25 \%$ to $50 \%$ of road de-icing salt may reach groundwater, increasing the salinity of drinking water sources in public distribution networks. Data on drinking water from several Canadian provinces indicate that the $\mathrm{Cl}$ concentrations are generally less than $10 \mathrm{mg} / \mathrm{L}$ [29]. In the present study, results showed that $\mathrm{Cl}$ concentrations in study wells (G3-G5) are very high, up to 22 times higher than $10 \mathrm{mg} / \mathrm{L}$. In the case of $\mathrm{Na}$, the concentration ranges in both the control wells (28-30 mg/L Na) and the study wells (37-112 mg/L Na) were within the normal ranges for groundwater in Canada (from 6 to $130 \mathrm{mg} / \mathrm{L}$ ) [30]. The concentrations of $\mathrm{Cl}$ and $\mathrm{Na}$ remained in all cases below the drinking water quality standards of Canada: $250 \mathrm{mg} / \mathrm{L}$ and $200 \mathrm{mg} / \mathrm{L}$, respectively [31]. However, results highlight that the highest $\mathrm{NaCl}$ concentration is found in the groundwater from the areas of the watershed affected by the road network (study wells), which makes it essential to perform long term monitoring.

\subsection{Surface Water Quality}

\subsubsection{Water Quality Indicators}

Table 2 shows the water quality indicators measured in influent (S1) and effluent (S2) surface water at the pilot site during summer and autumn, 2011, after its construction. During the first period of operation (from mid-2011), no significant differences were observed on water quality indicators between S1 and S2 sampling points. Nonetheless, a trend to decrease was observed on EC (from $1.9 \mathrm{dS} / \mathrm{m}$ at $\mathrm{S} 1$ to $1.1 \mathrm{dS} / \mathrm{m}$ at S2) with higher values during the summer period. A decreasing trend on the concentration of TSS was also observed, from $194.5 \mu \mathrm{g} / \mathrm{L}$ (S1) to $24.1 \mu \mathrm{g} / \mathrm{L}$ (S2), suggesting the retention of particles by the system.

Table 2. Water quality indicators (mean and range) measured in influent (S1) and effluent (S2) surface water in the pilot site after its construction, from late summer to autumn 2011.

\begin{tabular}{cccccccccc}
\hline \multirow{2}{*}{ Parameters } & \multicolumn{4}{c}{ Influent (S1) } & \multicolumn{5}{c}{ Effluent (S2) } \\
\cline { 2 - 10 } & Units & Min & Max & Mean & SEM & Min & Max & Mean & SEM \\
\hline $\mathrm{T}$ & ${ }^{\circ} \mathrm{C}$ & 9.1 & 17.5 & 14.1 & 1.8 & 8.9 & 19.2 & 16.3 & 2.5 \\
$\mathrm{pH}$ & - & 7.4 & 8.2 & 7.8 & 0.1 & 7.1 & 8.2 & 7.7 & 0.2 \\
$\mathrm{EC}$ & $\mathrm{dS} / \mathrm{m}$ & 0.7 & 2.8 & 1.9 & 0.4 & 0.6 & 2.2 & 1.1 & 0.3 \\
$\mathrm{TSS}$ & $\mu \mathrm{g} / \mathrm{L}$ & 2.2 & 386.8 & 194.5 & 192.3 & 12.4 & 35.8 & 24.1 & 11.7 \\
\hline
\end{tabular}

Notes: SEM: Standard error of mean; T: Temperature; EC: Electrical conductivity; TSS: Total suspended solids.

A comprehensive monitoring was completed between March and November in 2012. Data on climatic conditions (ambient temperature, and total precipitation) during this period are shown in Figure 7. Surface water quality indicators (water temperature, $\mathrm{pH}, \mathrm{EC}$, and TSS) in S1 and S2 sampling points along the performed monitoring are shown in Figure 8. 


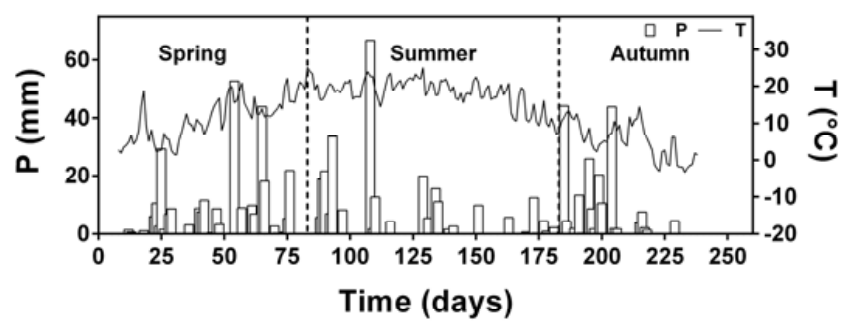

Figure 7. Precipitation and temperature from spring to autumn 2012 (Station Jean Lesage, Quebec).

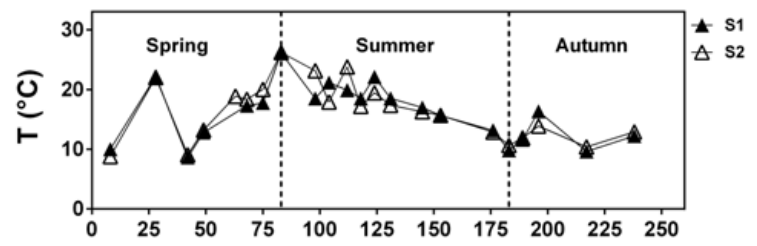

(a)

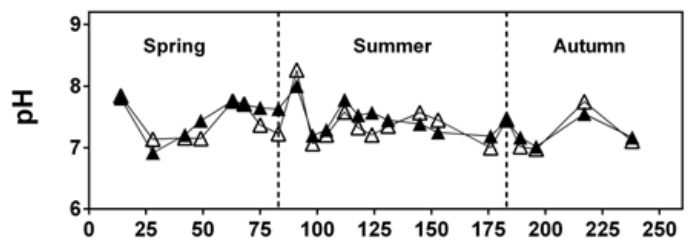

(b)

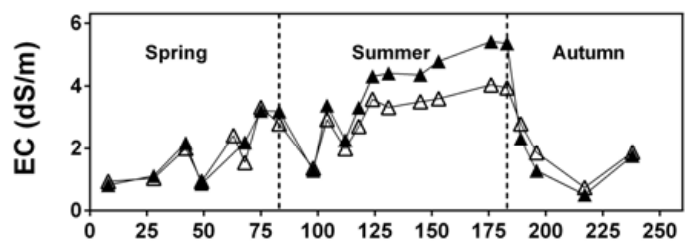

(c)

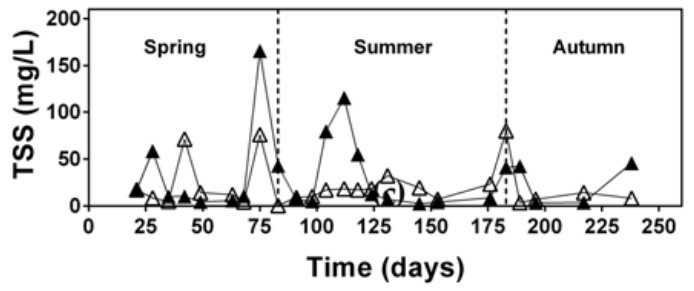

(d)

Figure 8. Water quality indicators in influent (S1) and effluent (S2) surface water along the monitoring performed in the pilot site from spring to autumn 2012: (a) temperature (T); (b) pH; (c) electrical conductivity (EC) and (d) total suspended solids (TSS).

Depending on the season, water temperature ranged from $8.6{ }^{\circ} \mathrm{C}$ (spring) to $26.2{ }^{\circ} \mathrm{C}$ (summer) (Figure 8a), and was generally related to the ambient temperature (Figure 7) with no differences from $\mathrm{S} 1$ to $\mathrm{S} 2$ sampling points. Water $\mathrm{pH}$ values were from neutral to moderately alkaline, between 6.9 and 8.3 (Figure 8b), suitable to permit the existence of most living organisms [32]. No pattern on $\mathrm{pH}$ values according to the season was observed, and no differences between influent and effluent water (S1 and S2). The values of EC in surface water (Figure 8c) were highly variable over time, as previously reported for road runoff $[5,33]$. The EC values ranged from 0.5 to $5.4 \mathrm{dS} / \mathrm{m}$ (S1) and from 0.7 to $4.0 \mathrm{dS} / \mathrm{m}$ (S2), consistent with the data obtained by Galvez-Cloutier et al. [20] in road side ditches at the same section of the Highway A40. In contrast to that observed for groundwater, in the case of 
surface water, the highest EC values were measured in summer and the lowest in both autumn and the early spring. Thus EC values in August and September (3.3-5.4 dS/m) were up to four times higher than in April and May $(0.8-2.4 \mathrm{dS} / \mathrm{m})$. Low precipitation, associated with higher ambient temperature, increases salt concentration in water and hence EC. Indeed, this seasonal pattern observed on EC in surface water in both S1 and S2 points (Figure 8c) is consistent with the low total precipitation and high temperatures recorded from mid to late summer (Figure 7). In the fall, EC gradually declined according to the lowest ambient temperature, reaching values similar to those of early spring. Electrical conductivity at S2 was 25\% lower than at S1 during August and September, in accordance to that observed in 2011 (Table 2), thus suggesting salt removal by the system during this period.

Regarding particulate matter (Figure 8d), high fluctuations on TSS concentrations were observed in surface water in both S1 and S2 sampling points, with a range from $0.6 \mathrm{mg} / \mathrm{L}$ (minimum in S2) to $165.6 \mathrm{mg} / \mathrm{L}$ (maximum in S1). Values were low taking into account the traffic intensity of Highway A40 [34] and when compared with the TSS concentration ranges reported for road runoff in other studies: 18-3165 mg/L [33], 13-4800 mg/L [35], and 1-5100 mg/L [2]. Regarding rainfall, a positive relation was observed among the peaks in TSS concentration (Figure 8d) and the peaks in total precipitation (Figure 7), but significant correlations could not be established (Table 3). The concentration of TSS in road runoff is dependent on a number of factors including storms events, rainfall intensity and duration, an antecedent dry weather period, wind, traffic volume and type, traffic during storms, watershed extension, land use in surrounding areas (residential, urban, and agricultural), TSS particle size, and so on [35-38]. The complexity of interactions among these factors may account for the lack of significant correlations between TSS concentration and the climatic data. When comparing the annual average concentration of TSS between S1 and S2 points, a slight overall decrease was observed.

Table 3. Pearson's correlation coefficients among influent (S1) and effluent (S2) surface water parameters.

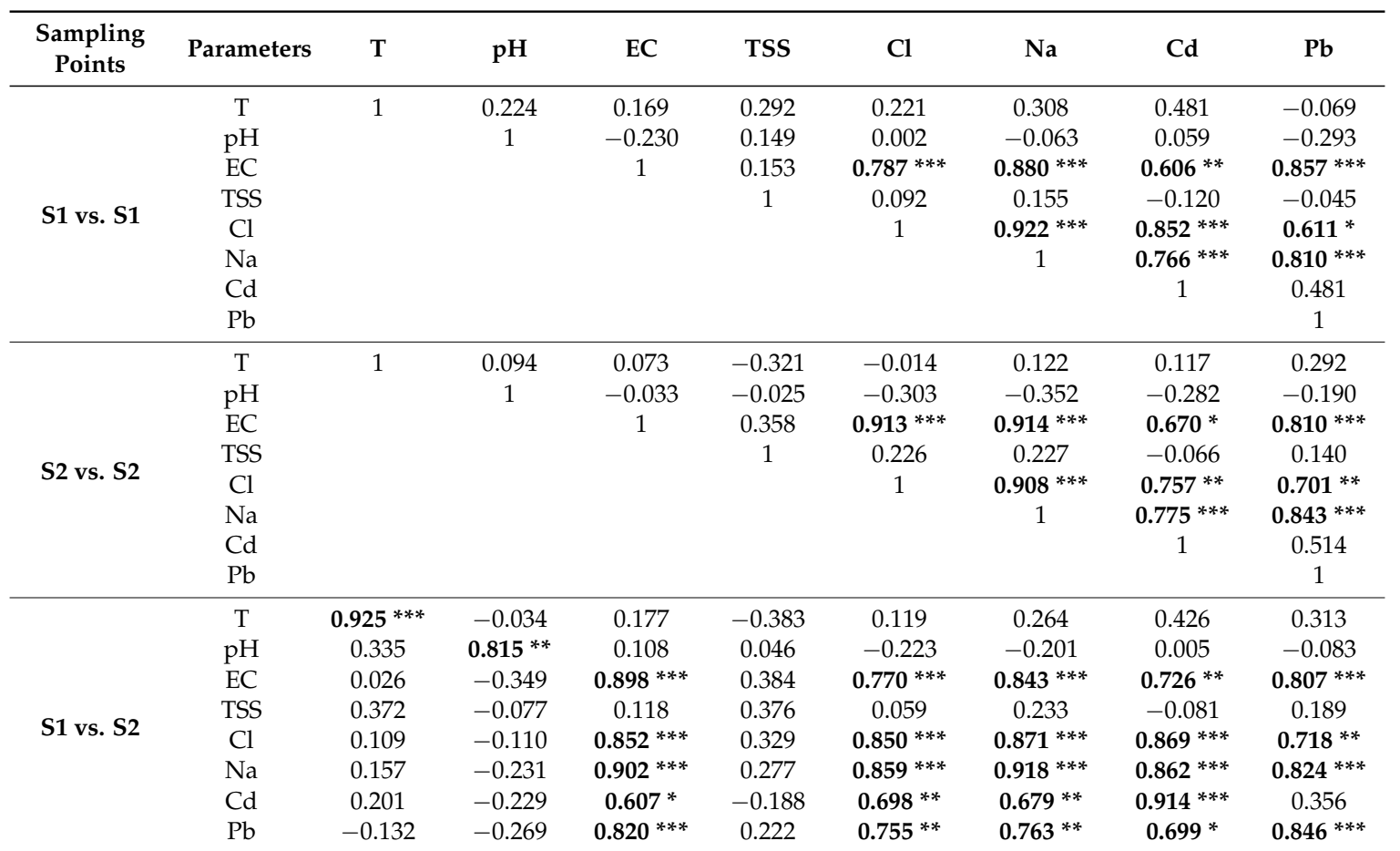

Notes: T: Temperature; EC: Electrical conductivity; TSS: total suspended solids. ${ }^{*} p<0.05$; ${ }^{* *} p<0.01 ;{ }^{* * *} p<0.001$, statistical significance at these probability levels $(n=26)$. 


\subsection{2. $\mathrm{NaCl}$ Concentration and Removal Efficiency}

The concentration of $\mathrm{Cl}$ and $\mathrm{Na}$ in surface water ( $\mathrm{S} 1$ and $\mathrm{S} 2$ points) along the monitoring performed in the pilot site from spring to autumn 2012 is shown in Figure 9.

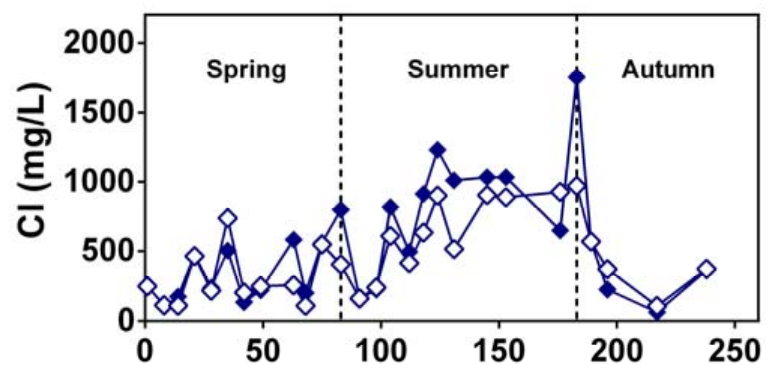

(a)

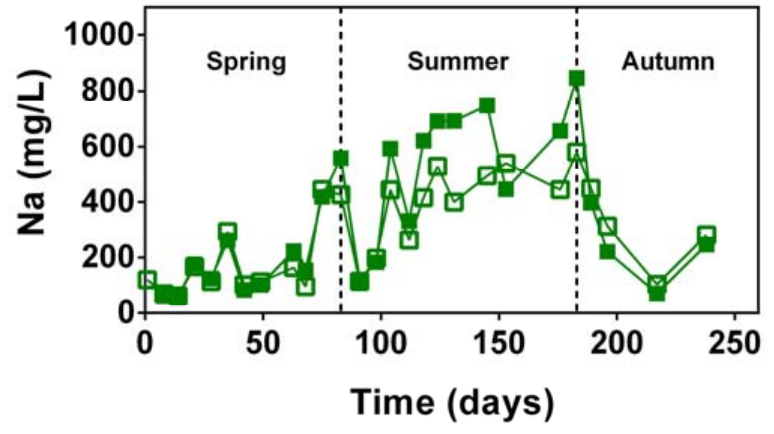

(b)

Figure 9. Concentration of $\mathrm{Cl}$ and $\mathrm{Na}$ in influent (S1) and effluent (S2) surface water along the monitoring performed in the pilot site from spring to autumn 2012: (a) $\mathrm{Cl}$ and (b) Na.

Overall, the $\mathrm{Cl}$ and $\mathrm{Na}$ concentrations measured in influent water (S1) were high and ranged from 63 to $1757 \mathrm{mg} / \mathrm{L} \mathrm{Cl}$ and from 61 to $846 \mathrm{mg} / \mathrm{L} \mathrm{Na}$. Values were in the same magnitude order as the concentrations reported prior to the pilot site construction [20] which suggests that the amount of de-icing salts used on Highway A40 (and in the road network around the highway) during winter road maintenance has not decreased in the last years. Data also revealed a salt pollution problem that may impacts the ecosystem services provided by surface water in the watershed [6]. The extreme salt concentration fluctuations (mostly in summer) can have severe impacts on the aquatic biota [5]. Indeed in $61 \%$ of influent water samples both $\mathrm{Cl}$ and $\mathrm{Na}$ concentrations exceeded the surface water quality criteria established by Quebec Environment Ministry for the prevention of contamination in water and aquatic organisms $(250 \mathrm{mg} / \mathrm{L} \mathrm{Cl}, 200 \mathrm{mg} / \mathrm{L} \mathrm{Na}$ ) [39]. Likewise, in $65 \%$ of samples, $\mathrm{Cl}$ concentrations exceeded the US Environmental Protection Agency chronic effect standard $(230 \mathrm{mg} / \mathrm{L} \mathrm{Cl})$ and in $23 \%$ the acute exposure standard $(860 \mathrm{mg} / \mathrm{L} \mathrm{Cl})$ for aquatic life in fresh water [40]. Data within the ranges are often reported for road runoff: $17-10,400 \mathrm{mg} / \mathrm{L} \mathrm{Na}$ [33], 1-298 mg/L Na and 1-573 mg/L $\mathrm{Cl}$ [8]. Nonetheless, the very high $\mathrm{NaCl}$ concentration fluctuations due to different site-specific and climatic conditions make comparability with other studies limited.

Positive and highly significant correlations $(p<0.001)$ between $\mathrm{Cl}$ and $\mathrm{Na}$ concentrations and $\mathrm{EC}$ values were obtained (Table 3). Indeed, $\mathrm{Cl}$ and $\mathrm{Na}$ concentrations and EC values in surface water, both in influent (S1) and effluent (S2), showed the same temporal pattern (Figures 8 and 9): increase in the mid and late summer, then decrease in autumn. Seasonal $\mathrm{NaCl}$ concentration ranges (both S1 and S2) were as follows: $61-559 \mathrm{mg} / \mathrm{L} \mathrm{Na}$ and 101-799 mg/L Cl (spring) < 114-846 mg/L Na and 158-1757 mg/L Cl (summer) > 71-449 mg/L Na and 63-569 mg/L Cl (autumn). Higher $\mathrm{NaCl}$ concentrations in winter during de-icing salt applications [5,33] or in spring after snow-melting [41] are 
often expected. However, data from the present study showed a clear increase of $\mathrm{NaCl}$ concentration in summer. The temporal pattern of $\mathrm{NaCl}$ concentration is linked to climatic conditions: the highest concentrations of $\mathrm{NaCl}$ in water at higher temperature and lower precipitation, i.e., higher temperature/precipitation ratio, as occurs in summer [42]. Indeed, as discussed above for EC, evaporation processes occurring during summer involve a decrease in surface water flow and then an increase in salt concentration in water. Therefore, our study suggests that high $\mathrm{Cl}$ and $\mathrm{Na}$ concentrations may be expected in the Saint-Augustin Lake watershed in summer. Chloride soluble concentrations in surface water were generally higher than Na concentrations (2-3 fold) (Figure 9). The $\mathrm{Cl}$ ions are very soluble and less favourable to be adsorbed onto soil colloids than $\mathrm{Na}$ ions which can be adsorbed due to cation exchange reactions by displacing cations such as $\mathrm{Ca}^{2+}$ and $\mathrm{Mg}^{2+}[42,43]$. The different affinity of $\mathrm{Cl}$ and $\mathrm{Na}$ for particle sorption may account for the molar imbalance observed between $\mathrm{Cl}$ and $\mathrm{Na}$ in surface water.

The seasonal performance of the pilot site (including detention basin, active filtering bed, and adapted constructed wetland units) was evaluated by calculating the $\mathrm{Cl}$ and $\mathrm{Na}$ removal efficiency considering the concentration difference between influent (S1) and effluent (S2) surface water (Equation (1)). The seasonal removal efficiency was as follows: $16 \% \mathrm{Cl}$ and $10.6 \% \mathrm{Na}$ (spring), $18.1 \% \mathrm{Cl}$ and $24.5 \% \mathrm{Na}$ (summer), and $19.7 \% \mathrm{Cl}$ and $3 \% \mathrm{Na}$ (autumn). Data corresponds to the first year of operation (2012). Higher performance is expected in the subsequent years with the maturation of the system due to growth and development of vegetation and the increase of micro- and macroorganism biomass and activity, as previously reported in adapted constructed wetland under cold climate [44]. Data showed a different removal pattern depending on the element, $\mathrm{Cl}$ or Na. Thus $\mathrm{Cl}$ removal remained almost constant over the pilot site operational period. However, in the case of $\mathrm{Na}$, the performance of the system was higher during summer, followed by spring, which deserves further studies.

\subsubsection{Trace Metal Concentration and Removal Efficiency}

The concentration of dissolved $\mathrm{Cd}$ and $\mathrm{Pb}$ in surface water (S1 and S2 points) along the monitoring performed from spring to summer 2012 is shown in Figure 10.

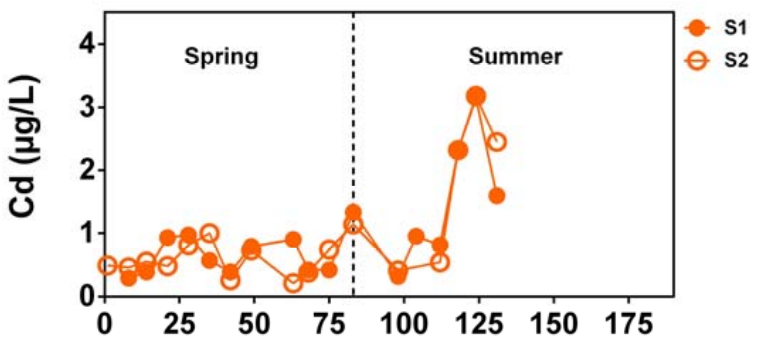

(a)

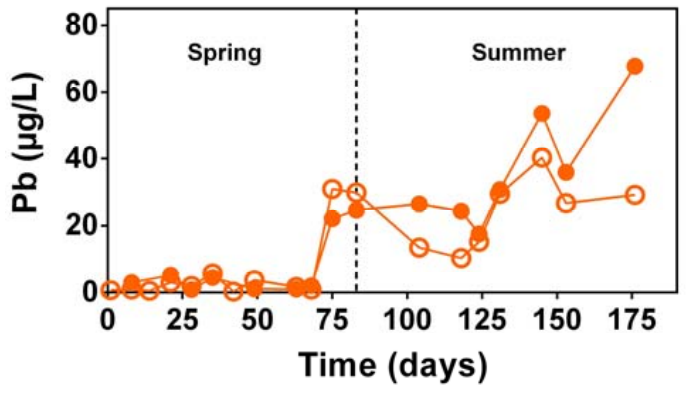

(b)

Figure 10. Concentration of trace metals in influent (S1) and effluent (S2) surface water along the monitoring performed in the pilot site from spring to summer 2012: (a) Cd and (b) $\mathrm{Pb}$. 
Cadmium and $\mathrm{Pb}$ concentration in autumn was not presented because it was below detection limit. Trace metal concentration in both S1 and S2 points ranged as follows: $0.2-3.2 \mu \mathrm{g} / \mathrm{L} \mathrm{Cd}(0.98 \mu \mathrm{g} / \mathrm{L}$ mean $)$ and $0.3-67.8 \mu \mathrm{g} / \mathrm{L} \mathrm{Pb}(16.6 \mu \mathrm{g} / \mathrm{L}$ mean). In all cases, $\mathrm{Cd}$ concentration was under the surface water quality criteria established by the Quebec Environment Ministry for the prevention of contamination in water and aquatic organisms (5 $\mu \mathrm{g} / \mathrm{L} \mathrm{Cd}$ [ [39]. In contrast, in 56\% of water samples, Pb concentrations exceeded the same quality criteria $(10 \mu \mathrm{g} / \mathrm{L} \mathrm{Pb})$. However, according to USEPA [40], in $97 \%(\mathrm{Cd})$ and $71 \%(\mathrm{~Pb})$ of water samples the chronic effect standard for aquatic life in fresh water $(0.25 \mu \mathrm{g} / \mathrm{L} \mathrm{Cd}$ and $2.5 \mu \mathrm{g} / \mathrm{L} \mathrm{Pb}$ ) was exceeded, as well as in $15 \%(\mathrm{Cd})$ and $3 \%(\mathrm{~Pb})$ of the acute exposure standard $(2 \mu \mathrm{g} / \mathrm{L} \mathrm{Cd}$ and $65 \mu \mathrm{g} / \mathrm{L} \mathrm{Pb})$. The ranges of $\mathrm{Cd}$ and $\mathrm{Pb}$ concentration quantified in the present study were expectedly high because of the high daily traffic density in the Highway A40. High metal concentrations can also be related to the high amount of de-icing salts spread $[45,46]$ and the increased tear, wear, and corrosion due to the application of gravel at cold weather conditions [33]. Values are in line with those reported in other studies in road runoff: $0.02-6.1 \mu \mathrm{g} / \mathrm{L}$ dissolved Cd $(0.2 \mu \mathrm{g} / \mathrm{L}$ mean $)$ and $0.2-414 \mu \mathrm{g} / \mathrm{L}$ dissolved $\mathrm{Pb}(5.4 \mu \mathrm{g} / \mathrm{L}$ mean) in urban and non-urban highways [2]; $1.5-72.3 \mu \mathrm{g} / \mathrm{L}$ total $\mathrm{Pb}$ in urban highways during storm events [47]; $400 \mu \mathrm{g} / \mathrm{L}$ event mean $\mathrm{Pb}$ concentration in highways with $>30,000$ vehicles/day [48].

Significant positive correlations among $\mathrm{Cd}, \mathrm{Pb}, \mathrm{Na}$, and $\mathrm{Cl}$ concentrations were obtained $(p<0.001 \mathrm{Cd}$ and $\mathrm{Pb}$ vs. $\mathrm{Na}, p<0.01 \mathrm{Cd}$ and $\mathrm{Pb}$ vs. $\mathrm{Cl}$ ) (Table 3). Indeed, temporal patterns in $\mathrm{Cd}, \mathrm{Pb}, \mathrm{Na}$, and $\mathrm{Cl}$ concentrations in surface water (both in $\mathrm{S} 1$ and S2) were similar: increase from mid to late summer, then a decrease in autumn (Figures 9 and 10). As discussed above, the higher temperature/precipitation ratio occurring in summer can explain this result (Figure 7). The positive correlations may also be related to metal mobilization processes by the formation of metallic chlorocomplexes, favoured at pHs of the present study [41,49]. In this regard, Bäckström et al. [11] studied the seasonal variations of trace metals in soil solution as a function of the distance from the road in Sweden. They observed that the dominant speciation of $\mathrm{Cd}$ and $\mathrm{Pb}$ at $4 \mathrm{~m}$ from the road was: (i) $\mathrm{Cd}^{2+}, \mathrm{CdCl}^{+}$and $\mathrm{CdCl}_{2}$ (for $\mathrm{Cd}$ ); and (ii) $\mathrm{Pb}^{2+}, \mathrm{PbCl}^{+}$and $\mathrm{PbCO}_{3}$ (for $\mathrm{Pb}$ ). In road runoff, particulate matter is considered as one of the major pollutants since many pollutants are attached to it and washed off [37]. In the present study, significant Pearson correlations between $\mathrm{Cd}$ and $\mathrm{Pb}$ concentrations and TSS were not found (nor between TSS and $\mathrm{Cl}$ and $\mathrm{Na}$ ), even taking into account each season separately (Table 3). Despite $\mathrm{Cd}$ and $\mathrm{Pb}$ in road runoff are often associated with suspended solids, $\mathrm{Cd}$ and $\mathrm{Pb}$ adsorption can be far different depending on the fraction sizes, peaking at the fine particles $(<40 \mu \mathrm{m})$ [48]. In this regard, climatic conditions could play an important role. Westerlund et al. [50] observed that metals during snow-melting were more particulate bound than during the rainy periods with a higher percentage of the dissolved fraction. Nevertheless, at low ambient temperature the accumulation of metals in particles decreases [49]. Further studies considering the seasonal pattern of TSS particle size and trace metal distribution could be of great interest.

The seasonal performance of the pilot site was evaluated by $\mathrm{Cd}$ and $\mathrm{Pb}$ removal efficiency (Equation (1)). The seasonal removal efficiency in the first year of operation was as follows: $10.3 \% \mathrm{Cd}$ and $6.8 \% \mathrm{~Pb}$ (spring), and $-6.7 \% \mathrm{Cd}$ and $35.8 \% \mathrm{~Pb}$ (summer). As for $\mathrm{NaCl}$, higher performance is expected in the subsequent years. The negative removal rate of $\mathrm{Cd}$ in summer could be the result of pollutants entering the pilot site outlet, considering its proximity to the Highway A40 [34,47].

\section{Conclusions}

From this research project, conclusions about the groundwater and surface water monitoring conducted in the Saint-Augustin Lake watershed can be established. The concentrations of $\mathrm{Cl}$ and $\mathrm{Na}$ in groundwater were higher in study wells (affected by road network) than in control wells. Our findings suggest therefore that de-icing salts spread in the watershed roads impact the groundwater chemical composition. Regarding surface water, the pilot site (composed of a detention basin, an active filtering bed and an adapted constructed wetland) has been proposed as a solution to reduce the concentrations of $\mathrm{NaCl}$, as well as trace metals $(\mathrm{Cd}$ and $\mathrm{Pb})$, at a watershed scale. Monitoring of 
water surface showed that both $\mathrm{NaCl}$ concentrations and EC values follow a seasonal dependence. Thus, $\mathrm{NaCl}$ concentrations and EC values increased in mid and late summer (linked with the lowest precipitation and highest temperature recorded), and then decrease in autumn. The removal efficiency of $\mathrm{Na}$ by the pilot site was also dependent of the season, being the highest in summer, but constant in the case of $\mathrm{Cl}$. Cadmium and $\mathrm{Pb}$ concentrations were consistent with the traffic density and followed a similar temporal pattern to that observed for $\mathrm{NaCl}$ and $\mathrm{EC}$. The highest $\mathrm{Pb}$ removal was found in summer. The pilot site has shown to be a useful strategy to mitigate the impact of anthropogenic salinity at watershed scale, although it would take a few years of operation to observe its optimal performance. It should also be considered that the data are limited as an aggregate comparison of upstream/downstream of the pilot site, which is comprised of three units. This study deserves to be pursued and taken further in order to complete the data and to determine long-term conclusions.

Acknowledgments: The authors especially wish to thank Luke Pettet for English revisions. We thank the editor and the anonymous referees for helpful suggestions.

Author Contributions: Rosa Galvez conceived and designed the experiments; Hamdi Messaoud, Arthur Michaux and Samuel Roy performed the experiments; Gaëlle Guesdon, Ana de Santiago-Martín and Sébastien Raymond analyzed the data and wrote the paper.

Conflicts of Interest: The authors declare no conflict of interest.

\section{References}

1. Zhang, W.; Zhang, S.; Wan, C.; Yue, D.; Ye, Y.; Wang, X. Source diagnostics of polycyclic aromatic hydrocarbons in urban road runoff, dust, rain and canopy throughfall. Environ. Pollut. 2008, 153, $594-601$. [CrossRef] [PubMed]

2. Kayhanian, M.; Singh, A.; Suverkropp, C.; Borroum, S. Impact of annual average daily traffic on highway runoff pollutant concentrations. J. Environ. Eng. 2003, 129, 975-990. [CrossRef]

3. Environment Canada. Five-Year Review of Progress: Code of Practice for the Environmental Management of Road Salts. March 31; Environment Canada: Gatineau, QC, Canada, 2012.

4. Gouvernement du Québec. Stratégie Québécoise Pour une Gestion Environnementale des sels de Voirie. Bilan Québécois Annuel 2012-2013; Gouvernement du Québec: Quebec City, QC, Canada, 2014.

5. Meriano, M.; Eyles, N.; Howard, K.W.F. Hydrogeological impacts of road salt from Canada's busiest highway on a Lake Ontario watershed (Frenchman's Bay) and lagoon, City of Pickering. J. Contam. Hydrol. 2009, 107, 66-81. [CrossRef] [PubMed]

6. Cañedo-Argüelles, M.; Kefford, B.J.; Piscart, C.; Prat, N.; Schäfer, R.B.; Schulz, C.-J.J. Salinisation of rivers: An urgent ecological issue. Environ. Pollut. 2013, 173, 157-167. [CrossRef] [PubMed]

7. Novotny, E.V.; Stefan, H.G. Road Salt Impact on Lake Stratification and Water Quality. J. Hydraul. Eng. 2012, 346, 1069-1080. [CrossRef]

8. Daley, M.L.; Potter, J.D.; McDowell, W.H. Salinization of urbanizing New Hampshire streams and groundwater: Effects of road salt and hydrologic variability. J. N. Am. Benthol. Soc. 2009, 28, 929-940. [CrossRef]

9. Morteau, B.; Triffault-Bouchet, G.; Galvez, R.; Martel, L.; Leroueil, S.; Galvez, R.; Dyer, M.; Dean, S.W. Treatment of Salted Road Runoffs Using Typha latifolia, Spergularia canadensis, and Atriplex patula: A Comparison of their Salt Removal Potential. J. ASTM Int. 2009, 6. [CrossRef]

10. Galvez-Cloutier, R.; Saminathan, S.K.M.; Boillot, C.; Triffaut-Bouchet, G.; Bourget, A.; Soumis-Dugas, G. An Evaluation of Several In-Lake Restoration Techniques to Improve the Water Quality Problem (Eutrophication) of Saint-Augustin Lake, Quebec, Canada. Environ. Manag. 2012, 49, 1037-1053. [CrossRef] [PubMed]

11. Bäckström, M.; Karlsson, S.; Bäckman, L.; Folkeson, L.; Lind, B. Mobilisation of heavy metals by deicing salts in a roadside environment. Water Res. 2004, 38, 720-732. [CrossRef] [PubMed]

12. Kelting, D.L.; Laxson, C.L. Review of Effects and Costs of Road De-Icing with Recommendations for Winter Road Management in the Adirondack Park; Paul Smith's College: Saranac Lake, NY, USA, 2010.

13. Mayer, T.; Snodgrass, W.J.; Morin, D. Spatial characterization of the occurrence of road salts and their environmental concentrations as chlorides in Canadian surface waters and benthic sediments. Water Qual. Res. J. Can. 1999, 34, 545-574. 
14. Environment Canada and Health Canada. Canadian Environmental Protection Act, 1999. Priority Substances List Assessment Report. Road Salts; Environment Canada and Health Canada: Ottawa, ON, Canada, 2001.

15. Marsalek, J. Road salts in urban stormwater: An emerging issue in stormwater management in cold climates. Water Sci. Technol. 2003, 48, 61-70. [PubMed]

16. Boillot, C.; Triffault-Bouchet, G.; Soumis-Dugas, G.; Martel, L.; Galvez, R. Évaluation de la Compatibilité Ecologique d'une Technique de Restauration Pour lacs Eutrophes vis-à-vis du lac Saint-Augustin et de la Baie Missisquoi. Ministère du Développement Durable, de l'Environnement et des Parcs du Québec et Université Laval; Laval University: Quebec City, QC, Canada, 2010.

17. Pienitz, R.; Roberge, K.; Vincent, W.F. Three hundred years of human-induced change in an urban lake: Paleolimnological analysis of Lac Saint-Augustin, Québec City, Canada. Can. J. Bot. 2006, 84, 303-320. [CrossRef]

18. Bergeron, M.; Corbeil, C.; Arsenault, S. Diagnose Ecologique du lac Saint-Augustin. Document Préparé pour la Municipalité de Saint-Augustin-de-Desmaures par EXXEP Environnement, Québec, 70 Pages et 6 Annexes; EXXEP Environnement: Quebec City, QC, Canada, 2002.

19. Galvez-Cloutier, R.; Brin, M.-E.; Dominguez, G.; Leroueil, S.; Arsenault, S. Quality evaluation of eutrophic sediments at St Augustin Lake, Quebec, Canada. ASTM Int. 2003, 1442, 35-52.

20. Galvez-Cloutier, R.; Leroueil, S.; Pérez-Arzola, J.C. Le lac Saint-Augustin, sa Problématique d'eutrophisation et le lien avec les produits d'entretien de l'autoroute Félix-Leclerc. Rapport technique final 03605'3_06 présenté au ministère des Transports du Quebec. Volet II: Évaluation de la qualité des eau; Laval University: Quebec City, QC, Canada, 2006.

21. Roberge, K.; Pienitz, R.; Arsenault, S. Eutrophisation rapide du lac Saint-Augustin, Québec: Étude paléolimnologique pour une reconstitution de la qualité de l'eau. Nat. Can. 2002, 126, 68-82.

22. Gouvernment of Canada. Historical Data. Available online: http://climate.weather.gc.ca/historical_data/ search_historic_data_e.html (accessed on 16 March 2013).

23. Consortium Dessau-Soprin. Étude D'opportunité de L'autoroute Félix-Leclerc sur le Territoire de la Ville de Québec; Dessau-Soprin: Quebec City, QC, Canada, 2004.

24. Galvez, R.; Leroueil, S.; Triffault-Bouchet, G.; Martel, L.; Morteau, B. Natural geo-filter bed and halophyte wetland: An eco-engineering system to mitigate saline highway runoff impacts. In IASTED Technology Conferences; Alhajj, S.S., Leung, V.C.M., Petela, R., Saif, M., Thring, R., Eds.; ACTA Press: Banff, AB, Canada, 2010.

25. Messaoud, H. Aspects Hydrogéologiques et Suivi de la Qualité des Eaux Souterraines du Bassin Versant du lac Saint-Augustin: Impacts des sels de Déglaçage. Master's Thesis, Laval University, Quebec City, QC, Canada, 2015.

26. American Public Health Association (APHA). Standard Methods for the Examination of Water and Wastewater, 20th ed.; American Public Health Association: Washington, DC, USA, 1998.

27. Talbot Poulin, M.C.; Comeau, G.; Tremblay, Y.; Therrien, R.; Nadeau, M.M.; Lemieux, J.M.; Molson, J.; Fortier, R.; Therrien, P.; Lamarche, L.; et al. Projet D'acquisition de Connaissances sur les Eaux Souterraines du Territoire de la Communauté Métropolitaine de Québec, Rapport Final; Laval University: Quebec City, QC, Canada, 2013.

28. McConnell, H.H.; Lewis, J. Add Salt to Taste. Environ. Sci. Policy Sustain. Dev. 1972, 14, 38-44. [CrossRef]

29. Government of Canada. Guidelines for Canadian Drinking Water Quality: Guideline Technical Document-Chloride; Health Canada: Ottawa, ON, Canada, 1987.

30. Government of Canada. Guidelines for Canadian Drinking Water Quality: Guideline Technical Document-Sodium; Health Canada: Ottawa, ON, Canada, 1992.

31. Health Canada. Guidelines for Canadian Drinking Water Quality—Summary Table. Water and Air Quality Bureau, Healthy Enviroments and Consumer Safety Branch; Health Canada: Ottawa, ON, Canada, 2014.

32. Tchobanoglous, G.; Burton, F.L.; Stensel, H.D.; Eddy, M.; Metcalf \& Eddy, Inc. Wastewater Engineering. Treatment and Reuse, 4th ed.; McGraw-Hil: New York, NY, USA, 2003.

33. Helmreich, B.; Hilliges, R.; Schriewer, A.; Horn, H. Runoff pollutants of a highly trafficked urban road-Correlation analysis and seasonal influences. Chemosphere 2010, 80, 991-997. [CrossRef] [PubMed]

34. Kuoppamäki, K.; Setälä, H.; Rantalainen, A.-L.; Kotze, D.J. Urban snow indicates pollution originating from road traffic. Environ. Pollut. 2014, 195, 56-63. [CrossRef] [PubMed] 
35. Hallberg, M.; Renman, G.; Lundbom, T. Seasonal variations of ten metals in highway runoff and their partition between dissolved and particulate matter. Water Air Soil Pollut. 2007, 181, 183-191. [CrossRef]

36. Kayhanian, M.; Suverkropp, C.; Ruby, A.; Tsay, K. Characterization and prediction of highway runoff constituent event mean concentration. J. Environ. Manag. 2007, 85, 279-295. [CrossRef] [PubMed]

37. Aryal, R.K.; Furumai, H.; Nakajima, F.; Boller, M. Dynamic behavior of fractional suspended solids and particle-bound polycyclic aromatic hydrocarbons in highway runoff. Water Res. 2005, 39, 5126-5134. [CrossRef] [PubMed]

38. Lee, J.H.; Bang, K.W. Characterization of urban stormwater runoff. Water Res. 2000, 34, 1773-1780. [CrossRef]

39. Ministère Développement Durable Environnement Faunes des Parcs (MDDEFP). Critères de Qualité de l'eau de Surface 2013, 3e Edition, Québec, Direction du Suivi de l'état de L'environnement; Gouvernement du Québec: Quebec City, QC, Canada, 2013.

40. United States Environmental Protection Agency (USEPA). National Recommended Water Quality Criteria-Aquatic Life Criteria Table; US Environmental Protection Agency: Washington, DC, USA, 2016.

41. Li, F.; Zhang, Y.; Fan, Z.; Oh, K. Accumulation of De-icing Salts and Its Short-Term Effect on Metal Mobility in Urban Roadside Soils. Bull. Environ. Contam. Toxicol. 2015, 94, 525-531. [CrossRef] [PubMed]

42. Rhodes, A.L.; Newton, R.M.; Pufall, A. Influences of land use on water quality of a diverse New England watershed. Environ. Sci. Technol. 2001, 35, 3640-3645. [CrossRef] [PubMed]

43. Cooper, C.A.; Mayer, P.M.; Faulkner, B.R. Effects of road salts on groundwater and surface water dynamics of sodium and chloride in an urban restored stream. Biogeochemistry 2014, 121, 149-166. [CrossRef]

44. Harada, J.; Inoue, T.; Kato, K.; Uraie, N.; Sakuragi, H. Performance evaluation of hybrid treatment wetland for six years of operation in cold climate. Environ. Sci. Pollut. Res. 2015, 22, 12861-12869. [CrossRef] [PubMed]

45. Bäckström, M.; Nilsson, U.; Håkansson, K.; Allard, B.; Karlsson, S. Speciation of heavy metals in road runoff and roadside total deposition. Water Air Soil Pollut. 2003, 147, 343-366. [CrossRef]

46. Valtanen, M.; Sillanpää, N.; Setälä, H. The effects of urbanization on runoff pollutant concentrations, loadings and their seasonal patterns under cold climate. Water Air Soil Pollut. 2014, 225. [CrossRef]

47. Farrell, A.C.; Scheckenberger, R.B. An assessment of long-term monitoring data for constructed wetlands for urban highway runoff control. Water Qual. Res. J. Can. 2003, 38, 283-315.

48. Wong, T.; Breen, P.; Lloyd, S. Water Sensitive Road Design-Design Options for Improving Stormwater Quality of Road Runoff. Techical Report 00/1. Cooperative Research Centre for Catchment Hydrology; Cooperative Research Centre for Catchment Hydrology: Victoria, Australia, 2000.

49. Glenn, D.W.; Sansalone, J.J. Accretion and Partitioning of Heavy Metals Associated with Snow Exposed to Urban Traffic and Winter Storm Maintenance Activities II. J. Environ. Eng. 2002, 128, 167-185. [CrossRef]

50. Westerlund, C.; Viklander, M.; Bäckström, M. Seasonal variations in road runoff quality in Lulea, Sweden. Water Sci. Technol. 2003, 48, 93-101.

(C) 2016 by the authors; licensee MDPI, Basel, Switzerland. This article is an open access article distributed under the terms and conditions of the Creative Commons Attribution (CC-BY) license (http://creativecommons.org/licenses/by/4.0/). 